MIMBAR

JURNAL PENELITIAN SOSIAL DAN POLITIK

\title{
PROFESIONALISME ANGGOTA DPRD PROVINSI BENGKULU DALAM MENJALANKAN TUGAS POKOK DAN FUNGSI
}

\author{
Oleh: \\ Evsa Wulan Suri ${ }^{1}$
}

Email : evsawulansuri@gmail.com

\begin{abstract}
ABSTRAK
Penelitian ini hendak menganalisis profesionalisme anggota DPRD provinsi Bengkulu dalam menjalankan tugas pokok dan fungsi.Menggunakan metode kualitatif melalui pendekatan analisis kualitatif.Subjek penelitian adalah anggota DPRD Provinsi Bengkulu. Hasil penelitian (1) Secara keseluruhan aspek kompetensi, integritas, kredibilitas dan akuntabilitas yang merupakan indikator profesionalisme perlu dicapai guna memperbaiki kualitas legislator yang dibutuhkan publik, (2) Kualifikasi pendidikan dan pengalaman organisasi berpengaruh pada kompetensi legislator, (3) Fungsi kaderisasi partai politik yang belum terlaksana sempurna, (4) Sikap rasional rakyat dalam pilkada dipengaruhi sistem pemilu legislatif yang kompleks, (5) Alhasil sikap kurang profesionalisme memicu pelanggaran kode etik, kasus moralitas.
\end{abstract}

Kata Kunci : Profesionalisme, Tupoksi dan Pemerintahan Daerah.

\section{A. Pendahuluan}

Di era desentralisasi dan demokrasi memberi ruang dan peran DPRD yang semakin besar untuk menjadi mitra pemerintah dalam proses penyelenggaraan pemerintahan yang demokratis, bersih dan berwibawa. Pasal 40 Undang-Undang Nomor 32 Tahun 2004 menyebutkan bahwa DPRD merupakan lembaga perwakilan rakyat daerah dan berkedudukan sebagai unsur penyelenggara merintahan daerah dan merupakan salah satu unsur penyelenggara pemerintahan daerah disamping pemerintah daerah.

Secara formal, kualitas teknis anggota legislatif mengalami peningkatan, akan tetapi hal ini tidak berimplikasi secara signifikan terhadap peningkatan kinerja anggota legislatif. Banyak calon anggota legislatif yang tidak memiliki akar dalam masyarakat.Kondisi semacam ini menimbulkan banyaknya anggota legislatif yang berperan seperti seorang birokrat, yang berfikir bahwa mereka harus dilayani rakyat dan bukan sebaliknya.

DPRD sebagai lembaga politik perwakilan rakyat sering kali mendapat tanggapan beragam dari masyarakat.Pandangan masyarakat ini memacu pada pola kinerja DPRD dalam dinamika politik yang sedang berlangsung di negara ini.Isu-isu terhadap kinerjanya yang semakin berkaitan dengan kinerja invidualis seorang DPRD dalam menangani problema rakyat dirasa belum optimal dan profesional.

Eksistensi anggota DPRD yang belum pro public kerap mengecewakan konstituen..Seperti di DPRD provinsi saat ini, satu per satu kontroversi para pemegang janji rakyat ini terkuak melalui fakta oleh media dengan data-data akurat bersifat investigatif. Munculnya kasus korupsi seperti terjadinya OTT oleh tim saber pungli poda kepada anggota DPRD Bengkulu Tengah pada awal 2019 lalu, OTT oleh KPK terhadap ketua DPRD Bengkulu Selatan, Korupsi pengadaan jalan oleh ketua DPRD Seluma, perihal moralitas kasus perselingkuhan anggota dewan, kebijakan yang belum pro rakyat, kinerja yang mengecewakan, lebih dari lima raperda yang diindikasikan terbengkalai seperti raperda

${ }^{\square}$ Dosen Administrasi Negara Universitas Prof. Dr. Hazairin, SH 
MIMBAR

JURNAL PENELITIAN SOSIAL DAN POLITIK

Desember $2018 \quad$ ISSN : 2252-5270 \& E-ISSN : 2620-6056

Volume 7 No. 2

Tata ruang wilayah, transhipment tambang, zonasi atau RTRW, sehingga aspirasi rakyat terhambat untuk terealisasi.

Banyak aspek yang menjadi ekspektasi masyarakat terhadap anggota DPRD dilihat dari pendidikan, pengalaman organisasi, dan track record. Sosok pemimpin dalam 'frame' masyarakat adalah yang memiliki pendidikan ideal karena tuntunan kerja yang mengharuskan anggota DPRD memiliki kecerdasan dalam menjalankan tupoksi. Namun peraturan undang-undang yang tidak memberi batas minimal jenjang karir minimal strata satu, mengesankan perekrutan anggota dewan bersifat pragmatis dan tidak selektif. Mengenai kualifikasi pendidikan ini menimbulkan penilaian masyarakat bahwa anggota DPRD tidak dipandang sebagai yang berintelektualitas tinggi berdampak pada posisi wibawa anggota DPRD itu sendiri. Sedangkan jiwa kepemimpinan akan lahir dari sosok yang memiliki pengalaman di organisasi. Dalam organisasi banyak pengalaman yang mendukung kinerja anggota DPRD seperti pengalaman curah pendapat, teknik etika persidangan, dan lain lain.

Kondisi sistem pemilu legislatif di Indonesia begitu kompleks dengan banyaknya peserta calon legislative dari berbagai partai politik dimana jumlah parpol juga tidak sedikit. Kondisi demikian berdampak pada sikap tidak rasional masyarakat karena banyaknya calon yang harus dikenali apek aspek kompetensi serta bobot kualitas individu. Hal itu pula memicu katalisator politik uang oleh sejumlah oknum.

Fungsi kaderisasi belum berjalan optimal, dikarenakan hanya faktor kedekatan dengan parpol, populeritas atau memiliki modal yang berlimpah.Kombinasi kesemuanya itu melahirkan calon legislative yang tidak lagi diukur dari kompetensi sehingga berimplikasi pada prefesionalisme.

Profesionalisme ialah sifat-sifat (kemampuan, kemahiran, cara pelaksanaan sesuatu dan lain-lain) sebagaimana yang sewajarnya terdapat pada atau dilakukan oleh seorang rofessional. (Kamus Dewan Edisi Ketiga, ms 1057).Profesionalisme diadopsi dari akar kata profesion yang berarti berhubungan dengan profesion dan dibutuhkan keahlian dalam melaksanakannya (KBBI, 1994). Jadi, profesionalisme merupakan tingkah laku, kepakaran atau kualiti dari seseorang profesional (Longman, 1987).

Dari pengertian para ahli diatas dapat diambil beberapa indikator dari sebuah profesionalisme, adalah kompetensi, integritas, kredibilitas dan akuntabilitas anggota DPRD Provinsi Bengkulu dalam menjalankan tupoksinya. Maka berdasarkan uraian diatas, penelitian di fokuskan pada Profesionalisme yang dijalankan oleh anggota DPRD Provinsi Bengkulu dalam menjalankan tugas pokok dan fungsi.

\section{B. Metode Penelitian}

Penelitian ini menggunakan metode kualitatif dengan pendekatan secara analisis kualitatif, yang bertujuan memahami suatu situasi sosial, peristiwa, peran, interaksi dan kelompok. Metode pendekatan kualitatif merupakan sebuah proses investigasi. Peneliti juga lebih menekankan pada obyektivitas dan kejujuran yang diwujudkan dengan menjelaskan tujuan penelitian kepada informan (Creswell , 1994:150-1). Selain itu merahasiakan identitas informan, Data dan informasi yang digunakan dalam penelitian ini didapat dari observasi dan wawancara. penelitian ini bertujuan menggambarkan kondisi, informasi dan sifat sesuatu yang tengah terjadi dengan menuturkan, menganalisa dan mengklasifikasi serta menyelidiki melalui teknik pengumpulan data mengenai profesionalisme anggota DPRD Provinsi Bengkulu dalam menjalankan tupoksi.

\section{Hasil Penelitian}

Secara konseptual Profesionalitas Anggota Dewan Perwakilan Rakyat Daerah Provinsi Bengkulu, indikatornya adalah :

1. Kompetensi adalah derajat pengetahuan, pendidikan dan keahlian profesi yang mereka miliki dalam melakukan tugas-tugasnya menjungjung tinggi nilai intelektual, leadership dan menejemen yang berkualitas/ berkredibel. Secara harfiah, kompetensi adalah kapasitas, ketrampilan, atau kemampuan untuk melakukan sesuatu dengan benar dan secara efisien, atau suatu lingkup kemampuan seseorang atau suatu kelompok (Oxford Advance Learner's Dictionary of Current English, 1995:232). Menurut Collins Cobuild 
MIMBAR

JURNAL PENELITIAN SOSIAL DAN POLITIK

Dictionary (1993) "competence is ability to do something well or effectively" . Kompetensi memiliki pengertian yang sama dengan capability.

Konsep ini akan dilihat dan dikaji dengan indikator sebagai berikut :

1. Kesesuaian kualifikasi pendidikan/nilai intelektual dengan kompetensi/kapabiliti anggota DPRD.

2. Kemampuan, keahlian, dan pengetahuan untuk menjalankan tupoksi secara efektif dan efesien.

3. Sikap dan prilaku dalam konsep pribadi meliputi etika dan moral.

2. Integritas adalah memiliki integritas moral politik dan norma-norma kejujuran, kesetiaan dan kepeduliaan terhadap Negara dan masyarakat, konsekuen dan bertanggung jawab dalam menjunjung tinggi nilai keadilan, keterbukaan dan kesadaran terhadap hukum yang hakiki. Konsep ini akan dilihat dengan indikator berikut :

1. Konsistensi antara tindakan dan nilai dalam menjalankan profesionalitas yang selaras dengan tupoksi.

2. Komitmen para anggota dalam mewujudkan dan meningkatkan kualitas professional

3. Kredibilitas adalah kemampuan untuk menegakkan etika memikul amanah, setia pada janji dan kesepakatan, bersikap jujur, adil, dan rendah hati. Mampu menjadi penengah yang handal ketika terjadi suatu konflik di dalam perusahaan. Konsep ini akan dilihat dengan indikator sebagai berikut :

1. Kemampuan anggota DPRD Provinsi Bengkulu dalam membangun reputasi dan kepercayaan masyarakat.

2. Kemampuan anggota DPRD Provinsi Bengkulu dalam mencari pemecahan masalah public.

4. Akuntabilitas adalah "kewajiban untuk menyampaikan pertanggungjawaban atau untuk menjawab, menerangkan kinerja dan tindakan seseorang/badan hukum/pimpinan kolektif suatu organisasi kepada pihak yang memiliki hak atau kewewenangan untuk meminta keterangan atau pertanggungjawaban. Indikator sebagai berikut :

1. Kemampuan melakukan pertanggungjawaban kinerja manejerial dan program anggota DPRD Provinsi Bengkulu dalam menjalankan tupoksi.

2. Kewajiban memenuhi kepentingan masyarakat sebagai pemegang kedaulatan tertinggi.

Informan dalam penelitian ini adalah ketua fraksi/anggota Fraksi yang berjumlah 6 Fraksi. Beliau dipilih sebagai penetu informan berdasarkan perwakilan tiap fraksi-fraksi yang ada di DPRD Provinsi Bengkulu. Adapun informan pada tabel 6 yang berjumlah 6 orang adalah sebagai berikut :

\section{TABEL 2}

Daftar Anggota setiap fraksi yang menjadi responden/narasumber

\begin{tabular}{|c|c|l|l|}
\hline NO. & NAMA & FRAKSI & $\begin{array}{l}\text { KOMIS } \\
\text { I }\end{array}$ \\
\hline 1. & Informan 1 & GOLKAR & $\begin{array}{l}\text { KOMI } \\
\text { SI III }\end{array}$ \\
\hline 2. & Informan 2 & $\begin{array}{l}\text { DEMOKRA } \\
\text { T }\end{array}$ & $\begin{array}{l}\text { KOMIS } \\
\text { I I }\end{array}$ \\
\hline 3. & Informan 3 & PAN & $\begin{array}{l}\text { KOMIS } \\
\text { I IV }\end{array}$ \\
\hline 4. & Informan 4 & PKS & $\begin{array}{l}\text { KOMIS } \\
\text { I II }\end{array}$ \\
\hline 5. & Infroman 5 & $\begin{array}{l}\text { RAFLESIA } \\
\text { BERSATU } \\
\text { (KETUA) }\end{array}$ & $\begin{array}{l}\text { KOMIS } \\
\text { I IV }\end{array}$ \\
\hline 6. & Informan 6 & $\begin{array}{l}\text { PERJUANG } \\
\text { AN } \\
\text { RAKYAT } \\
\text { (SEKRETA } \\
\text { RIS })\end{array}$ & $\begin{array}{l}\text { KOMIS } \\
\text { I IV }\end{array}$ \\
\hline
\end{tabular}

\section{Pembahasan \\ Dewan Perwakilan Rakyat Daerah Provinsi Bengkulu dalam Menjalankan Tugas Pokok dan fungsi.}

\section{Indikator Kompetensi}

Menurut Collins Cobuild

Dictionary (1993), "competence is ability to do something well or effectively". Kompetensi memiliki pengertian yang sama dengan capability (kemampuan). Permasalahan kompetensi anggota DPRD 
MIMBAR

JURNAL PENELITIAN SOSIAL DAN POLITIK

adalah kualifikasi pendidikan, keterampilan dan background pendidikan dari anggota DPRD Provinsi Bengkulu dalam setiap Komisi. Thoha (2002) mengemukakan faktor-faktor yang berpengaruh terhadap kompetensi anggota DPRD sebagai berikut:

1. Etika dan moral belum dijadikan penentu;

2. Sistem rekruitmen para anggota;

3. Kualitas pendidikan dan pengalaman para anggota;

4. Rendahnya motivasi para anggota untuk kepentingan rakyat; dan

5. Sistem pemerintah yang dipergunakan.

Persoalan pertama adalah berbasis kualitas individu anggota DPRD terutama etika dan moral. Masih maraknya kasus moralitas atau sikap tidak terpuji di ruang publik. Kompetensi harus dikaji perihal track record yang baik, jelas asal usul, nama baik, dan kiprah sosial. Sistem rekruimen yang tidak menetapkan standar pendidikan ideal sehingga kualitas SDM di DPRD tergolong rendah, umumnya kurang berpengalaman tentang pemerintahan. Proses rekruitmen tidak berdasarkan kompetensi individu, melainkan berdasarkan kedekatan pada pengurus partai. Dampaknya anggota legislatif masih lemah dalam membuat produk kebijakan.

Berdasarkan hasil wawancara dari masing-masing perwakilan dari fraksi penulis mendapatkan data Menurut informan 1 adalah :

"kualifikasi pendidikan sebaiknya minimal D3 atau memiliki standar pendidikan di perguruan. namun sistem perekrutan para dewan yang sudah Berdasarkan pada Undang-Undang No. 10 Tahun 2008 syarat menjadi DPRD untuk dapat mengajukan diri sebagai calon legislatif / caleg".

Sedangkan menurut informan 2 memiliki pandangan :

" Bahwa Undang-Undang sudah benar, namun "sebaiknya" standar pendidikan calon legislatif minimal S1 dengan alasan para pengemban rakyat juga harus memiliki kualitas yang baik.Selain itu seiring perkembang zaman atau factor ke'kini'an undang-undang tentang syarat minimal calon legslislatif sebaiknya diubah. “
Ungkapan berbeda disampaikan informan di komisi IV, menginginkan kualifikasi pendidikan di legislatif adalah standar S2, hanya saja beliau berharap ada dana yang dianggarkan untuk para anggota legislatif agar kesemuanya bergelar Master untuk menambah kualitas edukasi yang memang juga sebagai faktor pendukung profesionalitas di parlemen.

Sudut pandang yang berbeda disampaikan salah satu anggota dari fraksi PKS,

"Tidak masalah dengan standar pendidikan minimal SMU/Sederajat, karena di dalam legislasi adalah tentang sosial dan politik, artinya, seroang anggota legislatif yang diutamakan adalah kompetensinya dalam bidang sosial sebagai perwakilan rakyat, penyambung aspirasi rakyat dan kemampuan politik yang sudah dikuasai sebelumnya (track record), baik yang didapati dalam organisasi ataupun pengalaman sebelumnya. Eduksi hanya factor pendukung agar lebih memantabkan perannya dalam menjalankan tupoksi. “

Dalam memahami peraturan perundang-undangan, sekurang-kurangnya para anggota DPRD tersebut harus menguasai azas-azas penyusunan rancangan suatu peraturan daerah, khususnya yang terkait dengan aspek filosofis, yuridis, ekonomis, dan sosiologis.

Menurut informan dari partai besar, menyimak dari lemahnya kompetensi anggota DPRD di bidang legislasi.Mereka belum menguasai pengetahuan dan kekerampilan di bidang legal-drafting, substansi Ranperda yang sedang dibahas, maupun persoalan sikap perilaku. Seperti yang disampaikan informan 7 :

"Adalah tanggung jawab parpol dalam mempersiapkan kader yang lulus uji dan berkualitas sehingga ketika kader duduk di legislatif mereka tidak mempermalukan parpol, namun membanggakan parpol. Partainya sendiri sejauh ini sudah melakukan seleksi yang ketat berkenaan dengan kompetensi individu kader mereka dengan mengirim para anggota dewan ke seminar dan loka karya baik di tingkat lokal maupun nasional, serta melaksanakan studi 


\section{MIMBAR}

JURNAL PENELITIAN SOSIAL DAN POLITIK

Desember $2018 \quad$ ISSN : 2252-5270 \& E-ISSN : 2620-6056 $\quad$ Volume 7 No. 2

banding. Selain itu fraksi kami menilai calon legislasi yang akan diusung di parlemen dari parpol kami narus dilihat dari dedikasi dan kapabilitas dalam penyampaian ide dan garasan, trackrecord positif dan penilaianpenilaian lainnya."

Sistem multipartai di DPRD tidak ada suara yang dominan menjadi penyebab sulitnya menciptakan produk legislasi dari segi kuantitas apalagi kualitas. Yang perlu dilakukan para anggota DPRD provinsi Bengkulu adalah pemahaman tentang hukum dan peraturannya, teknik tentang pembuatan peraturan, teknik penggunaan istilah nomenklatur hukum dan pemerintahan, dan teknik penyusunan peraturan perundang-undangan sehingga peningkatan kompetensi pada bidang penyusunan anggaran ini menjadi sangat penting melalui program up-grading penguasaan akuntansi.

Dari data personal yang diwawancara, beberapa anggota fraksi yang duduk di keanggotaan komisi yang membidangi tidak semuanya sesuai dengan background pendidikan dalam menjalankan fungsi legislasi.Penemapatan anggota komisi tidak selalu memiliki kualifikasi yang sesuai dengan bidang-bidang dalam komisi. Namun dalam menyamakan persepsi dengan kualifikasi berbeda kerap mengurai debat, seperti para anggota dewan yang enggan menerima masukan dari pihak luar.

Mengenai fungsi Pengendalian/ Kontrol sejauh ini, para anggota DPRD Provinsi Bengkulu masih belum memiliki kompetensi seperti yang terkait dengan persoalan pengendalian tersebut. Kunjungan kerja dalam rangka agenda peningkatan SDM alih alih dipandang dewan untuk meningkatkan kapasitas dalam menjalankan fungsi pengawasan dan memberikan penguatan dalam melaksanakan tupoksinya.

Dalam wawancara peneliti/penulis bersama informan 4, kunjungan kerja atau kunker dewan sudah efektif, hanya saja kelemahannya tidak melibatkan SKPD agar dapat mempertanggungjawabkan hasil kunker secara nyata.Sementara untuk hasil kunker sendiri diserahkan kepada parpol. Sementara pendapat dari informan 5, kunker dapat memaksimalkan kinerja program dan membantu dalam mengatasi persoalanpersoalan yang ada di tengah-tengah masyarakat.

\section{Indikator Integritas.}

Integritas adalah bagian dari karakter lahirnya profesionalme. Integritas melahirkan efek kepercayaan publik yang tidak mengutamakan keuntungan pribadi perihal sebuah keputusan. Dalam memenuhi kewajiban dan tanggung jawab demi integritas tinggi adalah dengan mematuhi nilai-nilai etika dan moral terutama kejujuran.Terkait dengan hal ini, anggota legislatif dapat diberhentikan bila tersandung alasan administratif, dan alasan yang berkaitan dengan kinerja dan integritas anggota DPR/DPRD merupakan kewenangan Badan Kehormatan DPR/DPRD untuk melakukan kontrol atas semua tindakan dan keadaan yang dijalani oleh anggota DPR/DPRD.

Adanya kasus korupsi seperti tindakan OOT KPK adalah bukti miskinnya integritas.Loyalitas anggota legislatif memudar seiring idiologi yang serba pragmatis dan transaksional.Oknum legislator yang terseret kasus korupsi masih diberi ruang lebar untuk kembali mencalonkan diri karena peraturan perundang-undangan masih belum tegas dan konsisten.Pertama, partai politik menjadi satu-satunya institusi yang mempunyai hak merekrut caleg. Pada saat yang sama partai politik tidak terlalu peduli dengan mutu integritas para calon anggota legislatif. Masih banyak parpol yang tidak tegas mensyaratkan integritas namun pada pragmatism yang sesat. Caleg petahana dianggap lebih memiliki kans lebih besar untuk dapat terpilih kembali dikarenakan modal besar baik modal materi maupun modal kekuasaan.

Peran integritas legislator dalam menyusun raperda juga masih lemah. Produk kebijakan undang-undang yang akan dikeluarkan hanya didiskusikan dalam waktu yang singkat saja. Tidak ada debatdebat yang ilmiah juga tidak dilengkapi dengan survei atau ujicoba sebelumnya sehingga mendapat banyak tantangan dari para ahli, akademisi, maupun masyarakat kebanyakan.

\section{Indikator Kredibilitas}

Kredibilitas merupakan salah satu 
MIMBAR

JURNAL PENELITIAN SOSIAL DAN POLITIK

Desember $2018 \quad$ ISSN : 2252-5270 \& E-ISSN : 2620-6056

Volume 7 No. 2

landasan untuk kepemimpinan yang produktif dalam arti membangun suatu reputasi yang melekat pada efektivitas pribadi positip.Kredibilitas dalam dimensi efektivitas pribadi, merupakan pondasi utama untuk membangun reputasi. Namun dalam memperoleh kredibilitas, bukanlah sesuatu yang gampang diraih oleh setiap anggota DPRD Provinsi Bengkulu, karena harus melalui suatu proses yang berkelanjutan dalam membangun kredibilitas sebagai wujud reputasi.

Kredibilitas menyangkut citra anggota dewan di mata rakyat. Kredibilitas juga menyangkut nama baik anggota dewan yang dikaji dari prilaku, etika dan komitmennya serta kemampuan dalam membuat perda. Kasus penipuan, korupsi, gratifikasi, perda-perda yang hanya menguntungkan pihak eksekutif-legislatif membentuk stigma buruk menyangkut kredibilitas dewan yang notabene menyandang predikat wakil rakyat, cenderung mementingkan kepentingan pribadi dan golongan.

Besarnya anggaran perjalanan dinas ini akhirnya membuat para wakil rakyat ini menjadi sibuk untuk menghabiskannya, bahkan saat ini hampir setiap minggu para anggota dewan provinsi ini melakukan perjalanan dinas. Konsekuensi sibuk melakukan perjalanan dinas harus dilakukan anggota dewan agar pada akhir tahun dimana seluruh anggaran perjalanan dinas telah dikeluarkan sehingga tidak ada lagi yang bisa dikembalikan ke kas daerah.

Dalam wawancara kepada informan dari fraksi Demokrat :

"Biaya kunker terbilang masih masuk akal karena untuk permasalahan biaya menginap di hotel sudah sesuai standar profesional dewan yang menjaga keeleganan seorang anggota dewan yang tidak mesti berlebihan tidak juga kurang.Begitu juga dengan biaya akomodasi dan transportasi yang terdang bisa saja membengkak pada waktuwaktu tertentu."

Selain itu anggota dewan belum sanggup membuktikan sepenuhnya tentang kredibilitas dalam merancang raperda, indikasi raperda yang banyak terbengkalai, kurangnya fungsi pengawasan di lapangan dan hal yg bersifat individual yakni yang menyangkut citra, kehormatan, martabat, citra sebagai lembaga penyelenggaraan pemerintah.

\section{Indikator Akuntabilitas}

Akuntabilitas kinerja anggota Dewan Perwakilan Rakyat Daerah terhadap masyarakat sebagai konstituen masih rendah.Ini bisa dilihat dari lemahnya fungsi penganggaran, legislasi, dan pengawasan.Akuntabilitas kinerja anggota Dewan Perwakilan Rakyat Daerah terhadap masyarakat sebagai konstituen juga rendah.Ini bisa dilihat dari lemahnya fungsi penganggaran, legislasi, dan pengawasan anggota DPRD yang terhormat. Dalam penganggaran, anggota DPRD kurang peka terhadap apa yang menjadi kebutuhan masyarakat sehingga Anggaran Pendapatan dan Belanja Daerah (APBD) menjadi tidak pro rakyat.

$\begin{array}{ccc}\text { Dalam fungsi legislasi } & \text { kurang } \\ \text { melibatkan } & \text { masyarakat } & \text { dalam }\end{array}$
prosesnya.Akibatnya, peraturan daerah (perda) yang dihasilkan kurang menyentuh persoalan yang dialami masyarakat.Hasilnya, perda hanya menjadi dokumen belaka.Implementasi perda di lapangan tidak maksimal.Dalam kondisi ini fungsi pengawasan dari DPRD terhadap eksekutif yang menegakkan perda juga tidak dijalankan maksimal.Tidak pernah ada konsultasi publik dengan melibatkan lebih banyak warga dalam membahas perda.Dewan cenderung studi banding yang menghabiskan banyak anggaran daripada meminta pendapat kelompok-kelompok masyarakat.

Menurut UU NO. 28 tahun 1999 tentang Penyelenggara Negara yang bebas KKN, dinyatakan bahwa setiap kegiatan dan akhir kegiatan penyelenggara Negara harus dapat dipertanggungjawabkan kepada masyarakat sebagai pemegang kedaulatan tertinggi Negara.

“...Masyarakat luas sebagai penilai objektif yang akan menentukan accountable atau tidaknya sebuah birokrasi. (Finner dalam Nico Andrianto 2007:23) Dengan demikian akuntabilitas merupakan kewajiban anggota DPRD Provinsi Bengkulu dalam hal memberikan pertanggungjawaban atau menjawab dengan memberi keterangan mengenai kinerja atas tindakan suatu organisasi kepada pihak yang memiliki hak dan kewenangan untuk 
MIMBAR

JURNAL PENELITIAN SOSIAL DAN POLITIK Desember $2018 \quad$ ISSN : 2252-5270 \& E-ISSN : 2620-6056 Volume 7 No. 2

meminta keterangan dan

pertanggungjawaban.Ketidakpedulian

terhadap hak-hak dan masalah dan cenderung menimbulkan peluang yang tinggi terhadap kurangnya akuntabilitas, terjadinya mal praktik, nepotisme, sogok menyogok (suap) dan korupsi. Hal tersebut dipicu penurunan nilai dan moral. Sikap hidup yang materialisme dan konsumerisme mendorong menurunnya moral dan tanggungjawab dalam melayani masyarakat.

Taufik (2010) mengatakan, derajat akuntabilitas bagi legislatif dilihat dari empat kategori, salah satunya kehadiran dewan dalam rapat, argumentasi, kuantitaskualitas, serta sanksi.Lemahnya komitmen DPRD Provinsi Bengkulu dalam tanggung jawab akuntabilitas politik yang mereka miliki, terutama di bidang legislasi.Penempatan anggota dewan dalam komisi atau panitia harus mempertimbangkan aspek politis. Di sisi lain, juga mempertimbangkan kemampuan substansi seperti pengalaman organisasi maupun latar belakang pendidikan. Jika hal itu dapat dilaksanakan, maka secara perlahan dan otomatis, kualitas perda-perda yang dihasilkan akan lebih baik.

\section{Kesimpulan dan Saran}

\section{Kesimpulan}

Profesionalitas anggota DPRD

Provinsi Bengkulu belum sepenuhnya dilaksanakan untuk menjalankan tugas pokok dan fungsi, hal tersebut penulis jabarkan dan dapat dilihat sebagai berikut :

1. Profesionalitas anggota DPRD Provinsi Bengkulu belum memenuhi standar profesi yang baik meliputi kompetensi, integritas, krebilitas dan akuntabilitas. Karena dari hasil pengamatan, wawancara dan observasi dilapangan ditemukan masih banyak anggota dewan yang tidak memenuhi ekspektasi publik atau rakyat. Sistem perekrutan kader dari parpol masing-masing masih dipertanyakaan kriteria dan sistem fit and proper testnya seperti apa. Dalam rapat paripurna dari keseluruhan fraksi masih kesulitan dalam menyamakan pendapat karena begitu banyak parpol dan fraksi serta background eduksi yang beragam, dampak dari sistem pemilu legislatif yang sedemikian kopleks. Banyak anggota dewan yang tidak begitu memahami mekanisme dalam menjalankan fungsi-fungsi tersebut dampak dari kompetensi kualifikasi pendidikan, pengalaman organisasi, serta track record kiprah sosial. Kompetensi anggota DPRD Provinsi Bengkulu secara keseluruhan masih di bawah standar karena karena memiliki SDM yang kurang berpengalaman di bidang pemerintahan dan politik sosial akibat proses rekruitmen yang tidak berdasarkan kompetensi individu, melainkan berdasarkan kedekatan pada pengurus partai, populeritas atau bermodal besar.

2. Integritas anggota DPRD Provinsi Bengkulu juga masih belum terjaga, solid dan utuh. Tuntutan agar para wakil rakyat (anggota DPR/DPRD) menunjukkan kinerja serta integritas adalah memiliki hati nurani yang bersih, mempunyai prinsip moral yang tangguh, adil serta jujur, dan tidak takut pada siapapun hanya kepada tuhan. Hal ini terbukti dengan masih banyaknya kasus-kasus hukum yang menjerat keanggotaan legislatif.

3. Kredibilitas anggota DPRD Provinsi Bengkulu menyangkut citra anggota dewan di mata rakyat yang disebut pula sebagai reputasi. Stigma yang melekat pada kredibilitas dewan di mata masyarat masih buruk. Kredibilitas menyangkut nama baik anggota dewan dikaji dari prilaku, etika dan komitmennya serta kemampuan dalam melaksanakan tupoksi. Kasus penipuan, korupsi, gratifikasi, perda-perda yang hanya menguntungkan pihak eksekutiflegislatif menyangkut kredibilitas dewan yang notabene menyandang predikat wakil rakyat, cendrung mementingkan kepentingan pribadi dan golongan.

4. Akuntabilitas kinerja anggota Dewan Perwakilan Rakyat Daerah terhadap masyarakat sebagai 
MIMBAR

JURNAL PENELITIAN SOSIAL DAN POLITIK

Desember $2018 \quad$ ISSN : 2252-5270 \& E-ISSN : 2620-6056 $\quad$ Volume 7 No. 2

konstituen masih rendah. Ini bisa dilihat dari lemahnya fungsi penganggaran, legislasi, dan pengawasan anggota DPRD yang dapat dipertanggungjawabkan. Dalam penganggaran, anggota DPRD kurang peka terhadap apa yang menjadi kebutuhan masyarakat sehingga Anggaran Pendapatan dan Belanja Daerah (APBD) menjadi tidak prorakyat. Selain itu kurang melibatkan masyarakat dalam prosesnya. Akibatnya, peraturan daerah (perda) yang dihasilkan kurang menyentuh persoalan yang dialami masyarakat.

\section{SARAN}

1) Sebaiknya peraturan undang-undang mengenai standar kualifikasi pendidikan disesuaikan dengan perkembangan zaman yang kompleks, menuntut wakil rakyat untuk cerdas dan berwibawa. Perlunya pertimbangan pengalaman organisasi calon legislatif agar efektif mengikuti mekanisme sidang dimana di dalamnya ada penyampaian gagasan, debat, curah gagasan, menyingkapi perbedaan, proses mufakat dan pengambilan keputusan sehingga menghasilkan produk kebijakan yang efesien dan pro rakyat. Partai politik dapat lebih selektif dalam Fungsi kaderisasi perekrutan calon legislatif dengan meninjau serius aspek aspek ukuran profesionalisme. Pemerintah yang berkompeten tegas dalam menegakkan hukum terutama praktik politik uang, sehingga calon legislator dipilih benarbenar berdasarkan pilihan hati nurani rakyat. Pemerintah dapat mengkaji ulang sistem pemilu legislatif yang kompleks, demi menghindari sikap tidak rasional masyarakat yang kesulitan mengenali calon legislatif sebagai pemicu katalisator politik uang.

\section{DAFTAR PUSTAKA}

Sumber dari Buku :

Amandemen Undang-Undang Pemerintahan Daerah 2008

Anwar Jasin, Peningkatan Mutu Sumber Daya Manusia, dalam M. Dawam
Raharjo.

Arikunto, Suharsimi, 1993. Manajemen Pengajaran Secara Manusiawi. Rineka Cipta, Jakarta.

H.A.R Tilaar. 2000. Paradigma Baru Pendidikan Nasional. Rineka Cipta, Jakarta.

Harefa Andrias, Membangkitkan Etos Profesionalisme, Gramedia Pustaka Utama, Jakarta

Horn dkk, 1973. The advanced Learner's Dictionary of Current English,Great Britain: oxford University

Isnanto, Rizal. 2009. Buku Ajar Etika Profesi, Semarang.

Keluar dari Kemelut Pendidikan Nasional, Menjawab Tantangan Kualitas Sumber Daya Manusia Abad 21, (Jakarta: Intermasa, 1997

Moleong, Lexy J., 2007, Metodologi Penelitian Kualitatif, Remaja Rosda Karya, Bandung

Pusat Bahasa Departemen Pendidikan Nasional, 2001.Kamus Besar Bahasa Indonesia. Balai Pustaka, Jakarta

Roestiyah, 1989.Masalah-Masalah Ilmu Keguruan. Bina Aksara, Jakarta.

Sarman, Hukum Pemerintahan Daerah di Indonesia, Rineka Citra, Jakarta

Surakhmad, winarno. 1994. Metode dan Teknik Akuntabilitas. Bandung

Tangkilisan, Hessel Nogi., Manajemen Publik, Grasindo, Jakarta

Toha, Miftah. 2000. Peran Ilmu Adminsitrasi Publik dalam Mewujudkan Tata Pemerintahan yang Baik.Yogyakarta. 